\title{
Determinants of Electricity Price in Competitive Power Market
}

\author{
Girish, G. P. ${ }^{1} \&$ Vijayalakshmi, S. ${ }^{1}$ \\ ${ }^{1}$ Department of Finance, IBS Hyderabad, IFHE University, India \\ Correspondence: Girish, G. P., Department of Finance, IBS Hyderabad, IFHE University, India. E-mail: \\ gpgirish.ibs@gmail.com
}

Received: July 22, 2013

Accepted: September 22, 2013

Online Published: October 15, 2013

doi:10.5539/ijbm.v8n21p70

URL: http://dx.doi.org/10.5539/ijbm.v8n21p70

\begin{abstract}
In this study we investigate the factors which determine electricity prices in competitive power markets. This study not only gives a snapshot of important factors to be considered while modelling and forecasting electricity prices but also addresses the issue of electricity spot price pre-processing techniques used in the literature and the Stylized facts related to electricity markets. This study encourages and motivates entrepreneurs to look at power trading sector, which has traditionally been a bastion of technical expertise, but now, has stakeholders from all sections of society and businesses particularly with growing influx of financial experts due to deregulation, liberalization of electricity markets and introduction of power/energy exchanges around the world.
\end{abstract}

Keywords: electricity price, modeling, determinants, forecasting, power exchange, competitive power market

\section{Introduction}

Over the last few decades, many countries around the world (both developed and developing nations) have taken the path of power market deregulation and liberalization. The basic objective of separation of services and infrastructure has been to introduce competition, transparency, accountability and increased efficiency and thereby transforming electricity markets from vertically integrated, centralized structure to a deregulated, open and competitive power market environment (Girish, Panda \& Rath, 2013; Weron \& Misiorek, 2008; Weron, 2006; Kirschen \& Strbac, 2004).

Electricity is now treated as a commodity worldwide which can be bought, sold and traded at market rates like any other commodity. It's a fact that Electricity as a commodity is probably the most important man-made commodity which is different from other commodities because it cannot be stored economically and it has to be consumed whenever it is produced (since electricity travels at the speed of light). This unique feature of electricity makes its prices exhibit some unique features like seasonality (at annual level, weekly level and daily level), mean reversion, volatility, price spikes or jumps. Any kind of variability in end user demand coupled with variations in weather conditions such as temperature, rainfall, precipitation, water reservoir levels etc. plays a pivotal role in electricity price behaviour. External events like outages of power plants or non-availability/shortage of coal for thermal power stations or any kind of breakdown of electrical transformers or imperfection in transmission grid reliability will result in having significant impact and effect on electricity prices.

All this makes electricity price modelling critical for power market participants. In this study we investigate the factors which determine electricity prices in competitive power markets. In Section 2 we review the stylized facts of electricity markets. In Section 3 we take a closer look at competitive power market, modelling and forecasting techniques used in literature along with electricity price pre-processing techniques. In section 4 we discuss the determinants of electricity prices in competitive power market and we summarize and conclude in Section 5.

\section{Stylized Facts of Electricity Market}

Electricity, if viewed from an economic perspective, is a non-storable good which makes balancing demand and supply a herculean task and it is always at a knife-edge. Even small changes in amount of electricity generated or change in demand can catapult into large changes in electricity prices in just a matter of few hours in competitive power markets. Spot electricity markets exhibit stylized facts such as Seasonality, Volatility, Mean-Reversion and Jumps/Spikes (see Bierbrauer, Menn, Rachev \& Trueck, 2007; Huisman \& Mahieu, 2003; Karakatsani \& Bunn, 2008; Girish et al., 2013). 
Real time balancing requirements of electricity supply and demand translates itself into seasonal behaviour of electricity spot prices in competitive electricity markets. Consumption of Electricity depends on the ever changing level of activities related to businesses i.e. commercial, industrial, household and also climatic conditions like temperature or the daylight hours available since it affects demand of electricity directly. This also makes demand of electricity seasonal with seasonal patterns within a day, week, month and year. This in turn affects electricity prices making it seasonal and cyclical depending on demand of electricity by commercial, industrial and household requirements.

A very strong mean reversion is observed in electricity market. In instances of increased demand, Electricity Generating stations having higher marginal costs will be used (ex: Oil, diesel) from supply side thereby increasing spot electricity prices. But when this demand returns to normal condition, these expensive generating stations will not be required to meet extra demand and are turned off thereby making spot electricity prices to revert back to its mean value. Unprecedented Volatility compared to any other financial or commodity market is observed for spot electricity prices. Any demand or Supply shock has critical impact on real time balancing because of non-storable nature of electrical energy coupled with inelastic nature of electricity demand over shorter time periods. Spot electricity prices are also prone to infrequent large spikes or jumps. This is essentially due to non-storability of electricity (economically) which implies that inventories (as used in other commodities) have no role in smoothening spot electricity price changes. Spikes or Jumps could also be accounted by generation capacity constraint, transmission problems (physical infrastructure limitations) and real time supply-demand balancing.

\section{Electricity Price Modeling and Forecasting Literature}

Electricity Price Modeling and Forecasting techniques used in the literature can be broadly divided into six classes namely Production-cost models, Equilibrium/game theoretic models, Fundamental/structural models, Quantitative/econometric/stochastic models, Statistical models and Artificial intelligence-based models (see Weron, 2006; Misiorek, Trueck \& Weron, 2006; Girish, 2013). Aggarwal, Saini \& Kumar (2009) classify Electricity Price forecasting Models broadly into 3 categories namely Game Theory Models, Time Series Models and Simulation models.

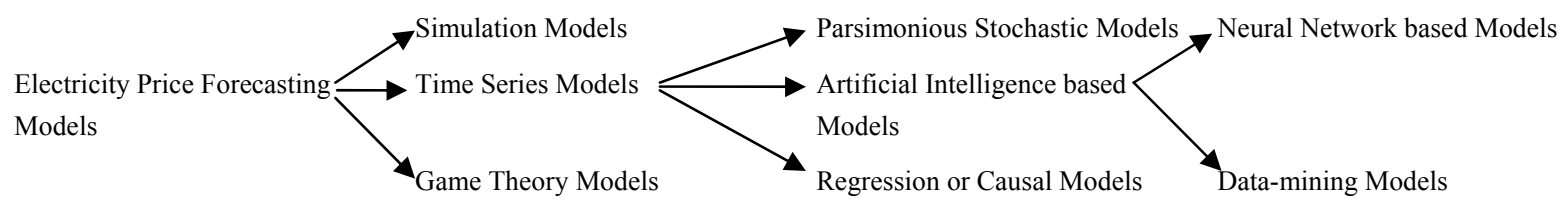

Figure 1. Electricity price forecasting models

Source: Aggarwal et al (2009).

Girish et al. (2013) have classified electricity price modeling and forecasting techniques based on the models used as shown in Table 1.

Table 1. Models used for spot electricity price modeling and forecasting

\begin{tabular}{|c|c|c|}
\hline S.I No. & Model & Authors \\
\hline 1 & Autoregressive Models & Cuaresma, Hlouskova, Kossmeier and Obersteiner (2004) \\
\hline 2 & ARMA Models & Carnero, Koopman and Ooms (2003) \\
\hline 3 & ARIMA Models & Contreras, Espinola, Nogales and Conejo (2003); Bowden and Payne (2008) \\
\hline 4 & $\begin{array}{l}\text { Dynamic Regression Models and } \\
\text { Transfer Function }\end{array}$ & Lora, Santos, Exposito, and Ramos (2002); Karakatsani and Bunn (2008) \\
\hline 5 & GARCH Models & Mugele, Rachev and Trueck (2005) \\
\hline 6 & $\begin{array}{l}\text { Multiple Linear Regression } \\
\text { Models }\end{array}$ & Schmutz and Elkuch (2004) \\
\hline 7 & Jump Diffusion Models & Knittel and Roberts ( 2005) \\
\hline 8 & Regime Switching Models & Ethier and Mount (1998); Haldrup and Nielsen (2004) \\
\hline
\end{tabular}

The models and studies related to modeling and forecasting of spot electricity prices have been empirically 
investigated in different competitive power markets having energy/power exchanges. Table 2 gives the timeline of establishment of power exchanges around the world (especially the day-ahead/spot electricity markets). In this list of power exchanges, it is interesting to know that India is the only country having peak power deficit and yet having a power exchange making it an interesting power market to investigate in future with an ultimate objective of modeling spot price dynamics of electricity prices and forecasting.

Table 2. Timeline of organized day-ahead markets (establishment of power exchanges)

\begin{tabular}{|c|c|c|}
\hline Country & Year & Name \\
\hline U.K. & 1990 & England \& Wales Electricity Pool \\
\hline Norway & 1992 & Nord Pool \\
\hline Sweden & 1996 & Nord Pool \\
\hline Spain & 1998 & Operadora del Mercado Espanol de Electricidad (OMEL) \\
\hline Finland & 1998 & Nord Pool \\
\hline U.S. & 1998 & California Power Exchange (CalPX) \\
\hline Netherlands & 1999 & Amsterdam Power Exchange (APX) \\
\hline U.S. & 1999 & New York ISO (NYISO) \\
\hline Germany & 2000 & Leipzig Power Exchange (LPX) \\
\hline Germany & 2000 & European Energy Exchange (EEX) \\
\hline Denmark & 2000 & Nord Pool \\
\hline Poland & 2000 & Towarowa Giełda Energii (Polish Power Exchange, PolPX) \\
\hline U.S. & 2000 & Pennsylvania-New Jersey-Maryland (PJM) Interconnection \\
\hline U.K. & 2001 & UK Power Exchange (UKPX) \\
\hline U.K. & 2001 & Automated Power Exchange (APX UK) \\
\hline Slovenia & 2001 & Borzen \\
\hline Poland & 2002 & Platforma Obrotu Energia, Elektryczna, (POEE) \\
\hline France & 2002 & Powernext \\
\hline Austria & 2002 & Energy Exchange Austria (EXAA) \\
\hline U.S. & 2003 & ISO New England \\
\hline Italy & 2004 & Italian Power Exchange (IPEX) \\
\hline Czech Rep. & 2004 & Operator Trhu s Elektrinou (OTE) \\
\hline U.S. & 2005 & Midwest ISO (MISO) \\
\hline Belgium & 2006 & Belgian Power Exchange (Belpex) \\
\hline India & 2008 & Indian Energy Exchange (IEX) \\
\hline India & 2008 & Power Exchange of India Ltd (PXIL) \\
\hline
\end{tabular}

Source: Weron (2006) \& Girish et al (2013).

In literature, we find authors making use of $\log$ of Spot electricity price $\left(\mathrm{S}_{\mathrm{t}}\right)$ which is assumed to be a sum of deterministic and stochastic components. There is no consensus about the technique to be used for electricity price pre-processing. Spot Electricity Price Pre-Processing can be achieved by (see Janczura, Trueck, Weron \& Wolff, 2013 for further details):

- Use of sinusoidal for deterministic seasonal component (see Bierbrauer et al., 2007; Keles, Hartel, Most \& Fichtner, 2012).

- Use of constant piece-wise function for deterministic seasonal component (see Knittel \& Roberts, 2005; Higgs \& Worthington, 2008).

- A combination of Sinusoidal and Constant piece wise function (see Bierbrauer et al., 2007).

- Fourier analysis and wavelet decomposition (see Weron et al., 2004; Janczura \& Weron, 2010).

\section{Factors Influencing Electricity Price in Competitive Market}

The role of a power exchanges is to match supply and demand of electricity so as to determine the market clearing price (MCP) or the spot electricity price. Factors influencing Electricity Prices can be classified under a) Fundamental factors like price of fuel (i.e., Coal, oil, gas), weather conditions, temperature, precipitation, 
rainfall, time indices such as day of the week, month of the year, season of the year and the cost of production of electricity per unit. b) Operational factors like electricity load electricity production levels (deficit/surplus), power transmission congestion in the grid, power system operating condition and also network maintenance. c) Strategic Factors like power market design, power purchase agreements, bilateral contracts between power market participants, Power Exchange and bidding strategies adopted by market players. d) Historical factors like prices and demand.

\begin{tabular}{|c|c|c|c|}
\hline & Factors influencing Electricity Prices & & \\
\hline $\begin{array}{ll}\text { Fundamental Factors } \\
\text { - } & \text { Fuel Prices } \\
\text { - } & \text { Temperature } \\
\text { - } & \text { Weather Conditions } \\
\text { - } & \text { Time indices such as day of the week, } \\
\text { - } & \text { Conth of the year, season of the year } \\
& \text { unit }\end{array}$ & $\begin{array}{l}\text { Operational Factors } \\
\text { - } \quad \text { Power Transmission } \\
\text { Congestion } \\
\text { - } \quad \text { Power System Operating } \\
\text { condition } \\
\text { - } \quad \text { Electricity production } \\
\quad \text { (deficit/surplus) } \\
\text { - } \quad \text { Network Maintenance } \\
\text { - } \quad \text { Electricity Load }\end{array}$ & $\begin{array}{ll}\text { Strategic Factors } \\
\text { - } \quad \text { Power Purchase } \\
\text { - } \quad \text { Agreements } \\
\text { - } \quad \text { Bilateral Contracts } \\
\text { - } \quad \text { Bidding Sxchange } \\
\text { - } \quad \text { Market Design }\end{array}$ & $\begin{array}{l}\text { Historical Factors } \\
\text { - } \quad \text { Price } \\
\text { - } \quad \text { Demand }\end{array}$ \\
\hline
\end{tabular}

Figure 2. Factors influencing electricity price in competitive power markets

In most of the power exchanges around the world, electricity trading in spot market is voluntary. Power market participants utilize this platform for hedging against price and volume risks. There is inconclusiveness in considering the factors for modeling and forecasting spot electricity prices in competitive power markets since electricity markets are regional and factors influencing price of electricity is different for different power markets. We find researchers using market clearing price of a spot market/day-ahead market for modeling and forecasting with an argument that the spot price of each-hourly contract truly reflects true market value and all the determinants of electricity price are factored into the market clearing price (see Cuaresma et al., 2004). Other researchers incorporate exogenous variables like load, demand, Cost of fuel (coal, oil, gas), wind energy, temperature, weather conditions, rainfall and water reservoir level for modeling and forecasting spot electricity price (see Weron et al., 2004; Weron, 2006; Aggarwal et al., 2009; Kristiansen, 2012).

Spot electricity price is defined as "The market clearing price (MCP) or Spot Electricity price is defined as the intersection of the supply curve (constructed from aggregated supply bids) and the demand curve (constructed from aggregated demand bids)" (Weron, 2006). In a spot electricity market, the spot electricity contract is an hourly contract with physical delivery. In a power exchange, these contracts are not traded on a continuous basis, but, are rather auctioned once per day (the day before the actual electricity delivery). Market clearing spot electricity prices is given by intersection of total demand and total supply curves for a particular hour for each region of the electricity market. When demand is low, the spot electricity price is not very sensitive to any demand shifts reason being that the supply stack is usually flat for low demand region. Whenever the demand is high, the extra electricity that has to be generated to meet the demand usually comes from expensive sources of power generation like generating stations using oil and gas. A small change or increase in electricity consumption can make these prices increase substantially. As soon as the demand drops or reduces, the spot electricity price rapidly reduces to normal levels and the electricity generating stations with higher fuel costs are not required and are turned off. Some of the factors that influence this supply stack include fuel prices volatility, power plant outages, maintenance related issues of physical infrastructure, constraints related to transmission, unforeseen constraints or breakdown of the power system network or grid and also market power.

\section{Conclusion}

Electricity, like any other commodity, can be bought, sold and traded at market rates. Many developing and developed nations around the world have embraced power market deregulation and liberalization with an objective of introducing competition. In the present study, we have investigated the factors which determine electricity prices in competitive power markets and reviewed the important factors to be considered while modelling and forecasting electricity prices. We have also addressed the issue of electricity spot price 
pre-processing techniques to be employed before modeling and forecasting spot electricity prices. The results of the study highlight factors influencing electricity prices which can be considered for modeling electricity prices and gives a new perspective for entrepreneurs and other power market participants to look at power trading sector, which, till 1990's, had been a bastion of technical expertise, but now, has stakeholders from all sections of society and businesses. With a growing influx of investments related to energy for securing energy supply particularly in this most important man-made commodity, investments in energy commodities by investors as a new asset class and the fact that many financial experts have stepped into energy trading due to deregulation, liberalization of electricity markets and introduction of power/energy exchanges around the world, we believe, energy trading is all set to catapult to a new level and the separation between technical business and financial service will shrink even further in days ahead.

\section{Acknowledgement}

We would like to thank Dr. Ajaya Kumar Panda and Dr. Badri Narayan Rath for all their valuable comments and feedback.

\section{References}

Aggarwal, S. K., Saini, L. M., \& Kumar, A. (2009). Electricity price forecasting in deregulated markets: A review and evaluation. Electrical Power and Energy Systems, 31, 13-22. http://dx.doi.org/10.1016/j.ijepes.2008.09.003

Bierbrauer, M., Menn, C., Rachev, S. T., \& Trueck, S. (2007). Spot and derivative pricing in the EEX power market. Journal of Banking and Finance, 31, 3462-3485. http://dx.doi.org/10.1016/j.jbankfin.2007.04.011

Bowden, N., \& Payne, J. E. (2008). Short term forecasting of electricity prices for MISO hubs: Evidence from ARIMA-EGARCH models. Energy Economics, 3186-3197. http://dx.doi.org/10.1016/j.eneco.2008.06.003

Carnero, M. A., Koopman S. J., \& Ooms, M. (2003). Periodic heteroskedastic Reg ARFIMA models for daily electricity spot prices. Tinbergen Institute Discussion Paper.

Contreras, J., Espinola, R., Nogales, F. J., \& Conejo, A. J. (2003). ARIMA models to predict next-day electricity prices. IEEE Transactions on Power Systems, 18(3), $1014-1020$. http://dx.doi.org/10.1109/TPWRS.2002.804943

Cuaresma, J. C., Hlouskova, J., Kossmeier, S., \& Obersteiner, M. (2004). Forecasting electricity spot-prices using linear univariate time-series models. Applied Energy, 77, 87-106. http://dx.doi.org/10.1016/S0306-2619(03)00096-5

Ethier, R., \& Mount, T. (1998). Estimating the volatility of spot prices in restructured electricity markets and the implications for option values. Cornell University Working Paper.

Girish, G. P. (2013). Spot Electricity Price Modelling and Forecasting. International Journal of Research in Commerce, IT and Management, 3(2), 154-157.

Girish, G. P., Panda, A. K., \& Rath, B. N. (2013). Indian Electricity Market. Global Business and Economics Anthology, 1, 180-191.

Haldrup, N., \& Nielsen, M. O. (2006). A Regime Switching Long Memory Model for Electricity Prices. Journal of Econometrics, 135(1-2), 349-376. http://dx.doi.org/10.1016/j.jeconom.2005.07.021

Higgs, H., \& Worthington, A. (2008). Stochastic price modeling of high volatility, meanreverting, spike-prone commodities: the Australian wholesale spot electricity market. Energy Economics, 30, 3172-3185. http://dx.doi.org/10.1016/j.eneco.2008.04.006

Huisman, R., \& Mahieu, R. (2003). Regime Jumps in Electricity Prices. Energy Economics, 25, $425-434$. http://dx.doi.org/10.1016/S0140-9883(03)00041-0

Janczura, J., \& Weron, R. (2010). An empirical comparison of alternate regime-switching models for electricity spot prices. Energy Economics, 32, 1059-1073. http://dx.doi.org/10.1016/j.eneco.2010.05.008

Janczura, J., Trueck, S., Weron, R., \& Wolff, R. C. (2013). Identifying spikes and seasonal components in electricity spot price data: A guide to robust modeling. Energy Economics, 38, 96-110. http://dx.doi.org/10.1016/j.eneco.2013.03.013

Karakatsani, N. V., \& Bunn, D. W. (2008). Forecasting Electricity Prices: The Impact of Fundamentals and Time-Varying Coefficients. International Journal of Forecasting, 24(4), 764-785. 
http://dx.doi.org/10.1016/j.ijforecast.2008.09.008

Keles, D., Hartel, R., Möst, D., \& Fichtner, W. (2012). Compressed-air energy storage power plant investments under uncertain electricity prices: an evaluation of compressed-air energy storage plants in liberalized energy markets. Journal of Energy Markets, 5(1), 53-84.

Kirschen, D., \& Strbac, G. (2004). Fundamentals of Power System Economics. John Wiley \& Sons Publication.

Knittel, C. R., \& Roberts, M. (2005). An empirical examination of restructured electricity prices. Energy Economics, 27(5), 791-817. http://dx.doi.org/10.1016/j.eneco.2004.11.005

Kristiansen, T. (2012). Forecasting NordPool day ahead prices with an autoregressive model. Energy Policy, 49, 328-332. http://dx.doi.org/10.1016/j.enpol.2012.06.028

Lora, A., Santos, J., Santos, J., Exposito, A., \& Ramos, J. (2002). A Comparison of Two Techniques for Next-Day Electricity Price Forecasting. Lecture Notes in Computer Science, 384-390. http://dx.doi.org/10.1007/3-540-45675-9_57

Misiorek, A., Trueck, S., \& Weron, R. (2006). Point and Interval Forecasting of Spot Electricity Prices: Linear vs. Non-Linear Time Series Models. Studies in Nonlinear Dynamics \& Econometrics, 10(3). http://dx.doi.org/10.2202/1558-3708.1362

Mugele, C., Rachev, S. T., \& Truck, S. (2005). Stable Modeling of Different European Power Markets. Investment Management and Financial Innovations, 3, 65-85.

Schmutz, A., \& Elkuch, P. (2004). Electricity Price Forecasting: Application and Experience in the European Power Markets. Proceedings of the 6th IAEE European Conference, Zurich.

Weron, R. (2006). Modeling and Forecasting Electricity Loads and Prices: A Statistical Approach. Wiley publication.

Weron, R., \& Misiorek, A. (2008). Forecasting spot electricity prices: A comparison of parametric and semiparametric time series models. International Journal of Forecasting, 24, 744-763. http://dx.doi.org/10.1016/j.ijforecast.2008.08.004

Weron, R., Bierbrauer, M., \& Truck, S. (2004). Modeling Electricity Prices: Jump Diffusion and Regime Switching. Physica, 39-48.

\section{Copyrights}

Copyright for this article is retained by the author(s), with first publication rights granted to the journal.

This is an open-access article distributed under the terms and conditions of the Creative Commons Attribution license (http://creativecommons.org/licenses/by/3.0/). 